\title{
STRATEGIC PEOPLE MANAGEMENT SKILL DIMENSIONS IN BUILDING SUSTAINABLE COMPETITIVE ADVANTAGE OF CHRISTIAN FAITH- BASED ORGANISATIONS IN NIGERIA: A CONCEPTUAL REVIEW
}

\author{
Joseph A. Dada ${ }^{1,2^{\star}}$, Rowland E. K. Worlu ${ }^{1}$, Adewale O. Osibanjo ${ }^{1}$, Daniel E. Ufua ${ }^{1,2}$, \\ Hezekiah O. Falola ${ }^{1}$ \\ ${ }^{1}$ Department of Business Management, Covenant University, Nigeria \\ ${ }^{2}$ Centre for Economic Policy and Development Research, Covenant University, Nigeria \\ ${ }^{*}$ Corresponding Author: joseph.dadapgs@stu.cu.edu.ng
}

\begin{abstract}
Purpose/Aim

In order to build principles in the organisational workforce and environment, strategic people management skills include articulating the selection of skills, expertise, competencies and personal qualities. This paper aims to explore how the implementation of strategic people management skills serves as a driver to sustainable competitive advantage in the competitive religious environment by utilizing the Christian FaithBased Organisations in Nigeria.
\end{abstract}

\section{Research Methodology}

A conceptual approach based on the analysis of historical trends in the implementation of people management skills, especially among Christian Faith-based organisations in Nigeria, based on current literature. Key factors necessary for the satisfactory implementation of strategic people management skills were identified which include training and re-training, career development and motivational factors.

\section{Research Findings}

Findings from extant literature show that beyond the operational strategic purview of Nigerian Christian Faith- Based Organisations, other critical factors such as environmental influence create a significant link between people management skills and the level of compliance from affected parties. This also partly determines the amount of resource requirement to support the implementation of people management projects. In terms of the aspirations of Christian Faith-Based Organisational leaders in Nigeria, environmental variables play a key role.

\section{Conclusion and Recommendations}

Based on these findings, we recommend that leaders should endeavour to define directional policy that enhances people management skills and establish measurable goals to meet members of staff, members and followers' expectations and to improve on organisational competitive advantage. Future research could be focused on empirical studies of Christian faith-based organisation in this direction.

Keywords: Christian Faith-Based Organisations, Strategic People Management Skills, Sustainable Competitive Advantage. 


\section{INTRODUCTION}

Organisation cannot achieve its meaningful purpose in term of efficiency, productivity, performance and sustainability if leaders are not at the helms of affairs to coordinate resources for sustainable competitive advantage (Abasilim, Gberevbie \& Osibanjo, 2019). Employees are recruited to perform specific task and job responsibility at various levels of an organisation. These employees are regarded as driving forces for the attainment of sustainable competitive advantage. They have individuals' aspirations to achieve and likewise to full the organisational aspiration on the other side. In spite of the nature of faith-based organisations (FBOs) as non-profit organisations, their employees needed to be trained and re-trained in such a way that they are fitted for the use of organisation to achieve the vision, mission and objectives.

Faith-based organisation is any organisation that draws inspiration and guidance from the teachings and principles of faith or from a specific understanding or school of thought within the faith for its activities. At a minimum, FBOs must be related either in the form of a particular philosophy of faith, employee recruitment, primarily volunteers, or leadership from a specific denomination of faith, with a structured faith group. Religiously focused mission statements, the reception of significant funding from a religious association or the initiation by a religious institution are other characteristics that qualify an association as "faith-based" (Clarke, 2015).

Religiously focused mission statements, the acceptance of considerable funding from a religious group or the initiation by a religious body is FBOs. From the perspectives of Nigeria religious environmental background, it is characterized by various religious dimensions. Religions such as Christianity, Islam, and African Traditional Religion (ATR) such as: Ogun, Oya, Sango, Obatala, etc.) and others (Hindus, Buddhism, Judaism, etc.) dominated the religious landmarks of Nigeria.

In the same vein, these religious non-profit organisations instil good moral behaviour and propagate their faith in the teaching and lesson of their various religion in our local communities. They have been recognised in the social impact assessment performance by many stakeholders because of excellent performance achieved in the areas where government of many nations have failed woefully due to corruption, ethnicity, and insincerity of purpose (Nzisi, 2017; Para-Mallan, 2019).

The major purpose of this study is that of identifying what strategic leaders considered useful in human work force to provide effective managerial insight in the church of nowadays and how those capabilities can be encouraged and sustained in achieving competitive advantage. The identification of people management skills enables leaders to develop sustainable programs and policies to acquaint people in the ministry. With such leadership relational skills would successfully allow leaders to cope with the environmental challenges faced with uncertainties in their FBOs. The study provided answer for the following research questions:

(i) In what way do training and re-training of members of staff including volunteers affect the attainment of sustainable competitive advantage?

(ii) What are the leadership programmes Christian FBOs can introduce to develop their members of staff and volunteers in order to attain sustainable competitive advantage?

(iii) What can the Christian FBO leaders do to motivate their members of staff, members and followers in the face of competitive religious environment for sustainability?

\section{CONCEPTUAL REVIEW}

\subsection{The Concept of Strategic People Management Skill}

The ability to handle people involved articulating the set of talents, experience, skills and personal characteristics that generated value in the workforce and workplace (Ireland and Hitts, 2015). Armstrong (2017) recognised that without recruiting and maintaining skilled workers with sufficient expertise, attitudes and skills, no company, whether profit or non-profit, will effectively execute its various activities. Casio and Montealegre (2016) thought that in this religious turbulence, adaptation to organisational requirements requires proper care of financial problems and the optimum deployment of available skilled human capital to achieve competitive advantage. Organisations today work in the world without set codes of conduct or a common style of leadership. There is no universal blueprint for success as a result. However, it is clear that a professional owner and leader, ideally someone with a business track record and in-depth knowledge of structured problems, should run the social enterprise. Therefore, training and re-training, job growth and 
motivational factors are facets of people management skills in this study.

When companies needed new skills, competitive strengths and operational methods, the challenges of training and retention of staff became important. In organisational efforts to develop skills-based competencies, preparation is strategically relevant (Oyedepo, 2016). Training was described by this scholar as an indication of the employees' superior skills, expertise and abilities that resulted in successful results. Training was perceived and defined by Murathimme-Nburu (2011) as a coordinated increase in the knowhow skills and sensations necessary for employees to perform their work in the organisation effectively. Akande (2016) also argued and endorsed the view that training equipped workers with unique job skills required to boost their results. In addition, the training provided critical work-related skills, strategies and employee awareness. Many scholars, such as Armstrong (2017) and Ubini (2018), have described training as an active means of enabling an employee to efficiently use his / her skill and abilities for the benefit of the organisation. They argued that successful organisations know that people management development gave them an organisational edge in this competitive religious environment. In FBOs, it is required that leaders are called of God and received spiritual inspiration to execute their activities in order to drive the mission statement and vision statement of the organisation competitively.

Also, Abioro, Olabisi, Onigbinde and Adedeji (2020) see career development as management decisions and actions that directly affected people as members of the organisations rather than as job holders. This was the stage where human factor of capability is involved. The development of people management is a value addition activity for the employee as well as organisation. Caplan (2014) cited in Sukier, Ramírez-Molina, Parra, and Martinez Cueto (2020) asserted that when an organisation fails to consider people development as a strategic tool, it can lead to the derailment of both the individual and the organisation. This aligned with the view of Armstrong (2017) that human capabilities are tailored toward the achievement of both individual aspirations and organisational aspirations. Christian FBOs can introduce long-life learning development programmes to boost capacity building in order to enhance their sustainable competitive advantage.

In addition, motivational factors are incentives that drive the performance, effectiveness of employees in the organisations. If its employees are not motivated, no business, whether formal or casual, can go far (Olofinkua, 2020). Armstrong and Taylor (2020) concluded that employees who lack attention or are uninterested in the overall objective are typically not very efficient and can sometimes weaken the efforts and authority of a leader. The remedy is often as simple as expressing the task clearly. In other cases, FBO leaders need to collaborate separately with workers to find out an appropriate reward framework. A great deal of worker motivation, for example, has to do with psychology in the workplace. The happier and more appreciated workers feel in FBOs, the more likely they are to send their best efforts to organisations. At times, engaging in employee satisfaction appears counterintuitive, but it is also seen as a significant error to disregard corporate culture.

It was therefore concluded on this note that FBOs will not be able to achieve their vision, mission and goals without adequate preparation for training of staff members; while primarily volunteers, career development and motivational factors, FBOs may not be able to achieve their vision, mission and goals and there is little to maintain.

\subsection{The Concept of Sustainable Competitive Advantage}

Going by the review of literature, the work of Barney (1991) in his book titled "firm resources and competitive advantage" and Grant (1991) titled "The resource-based theory of competitive advantage" cannot be ignored. Ceglinski (2016) sees competitive advantage of organisation as an achievement of success above average results of its business activities. The introduction of competitive advantage in strategic management assured that there are competitive advantages of sustainable characters. Sustainable competitive advantage can be gained by organisations such as FBOs if they have uncommon, important, imitable and nonsubstitutable resources. These organisations also can achieve temporary competitive advantage if they have only valuable and rare attributes (Barney, 1991; Grant 1991)

Therefore, competitive advantage allows an organisation to develop and acquire set of attributes that enhance performance to outs match its competitors. On the other hand, competitive advantage of FBOs reveals that activities of an organisation are more profitable than those of its competitors. For example, the advent of COVID-19 has changed the faces of doing business and religion world-wide, because many organisational plans and budgets have been disrupted due to this pandemic. The assumption of temporary competitive advantage comes in place in FBOs as a result of deepening globalisation, processes, technological disruption, climatic environmental turbulence, demographic challenge and change in taste and preferences. Strategy is becoming less about creating positions of sustainable competitive advantage as a result of continuous changes and relentless rivalry. 
According to Brimah, Bamidele and Rabiu (2020), the competitiveness of religious organisations in modern conditions is largely dependent on management's ability to ensure the required economic efficiency of operating operations, the achievement of strategic and tactical objectives, the reasonable use of labour, financial and material capital. This defines the importance of research on novel approaches to human skills to objectives-based management.

In addition, erosion of temporary competitive advantage becomes pronounced when dynamic and interactive rivalries are occurring routinely. The critical issue for competitive advantage to be sustainable is to be reoccurring over a stable number of times in the life of a religion organisation. Hence, leaders of FBOs have to look inward for the area of competence, competencies and competency in their policies guiding people management skill and operations to achieve pre-determined organisational objectives.

\subsection{The Concept of Faith-Based Organisations}

Faith-based organisations (FBOs) are development organisations with unique religious identities by religious body membership, mission statement and decision-making on religious beliefs, religious financial sources, religious belief-based governance structure. (Clarke, 2015; Glosnek, 2017). Churches, mosques, temples are also considered as FBOs. They acted as change agents in our societies by spreading the gospel, refining our moral characters, instilling their faith practices in the lives of members and lessen the burdens of members in our communities. FBOs are development organisations that impact both developed and developing economies in their contribution to the Gross Development Product, creation of social amenities, political development and creation of employment opportunities and war against social exclusion of the lessprivilege masses (Baiyeri, 2015; Clarke, 2015; Nwokoro, 2017; Tomalin, Haustein \& Kidy, 2018).

\subsection{Theoretical Review}

\subsubsection{Dynamic Capability Theory (1994)}

Teece and Pisano (1994) developed the theory. In order to gain short-term competitive advantage leading to organisational growth and survival, the premise of this theory was to investigate the capacity of organisations to rapidly organize and reconfigure externally sourced skills (Lim, Stratopoulos \& Wirjanto, 2013). The theory of dynamic capacity is an outcome of the theory of resource-based opinion. While the theory of resourcebased views is concerned with how an organisation can gain competitive advantage, the theory of dynamic capacity is more concerned with short-term competitive advantage that can be used to create long-term growth and sustainability competitive advantage (Lim, et al, 2013).

The theory of dynamic capability focuses on a company's ability to rapidly learn about changes and developments that are occurring in the religious climate. This helps companies to develop strategic assets to compete and turn existing assets within the organisation in order to respond to changes that arise in the religious environment for improved operational efficiency.

The arguments against the theory of dynamic capability are that the theory in terms of details is incomplete (Elbana, et al., 2020). Critics also pointed out that when there is a need for a change and when there is no change, the principle cannot be clarified (Steenstra, Gelderman \& Semeijn, 2020). There are still no clear information describing the cost of opportunities for improvements generated within the organisation, and there is a need to better align the theory with organisational theory (Li \& Liu, 2014). Dynamic ability therefore assumes that capabilities are the basic process, operations or routines of the company and put immutability of the company's ability to construct and reconfigure the resource base as the key to attaining competitive advantage (Lin \& Wu, 2014).

Arifin and Dewi (2020), however, argue that dynamic capabilities allow companies to have a competitive edge on an ongoing basis and can help companies avoid creating core rigidities that hinder developmental inertia and stifle innovation. Kirtmollaiev (2020) further points out that the deployment of dynamic capabilities can result in four different outcomes. First, if the generated resource base is not imitated over a long period of time and the rents are maintained, they may contribute to sustainable competitive advantage. Secondly, they may contribute to a temporary advantage. Third, they can only have competitive advantage if their influence on the resource base is simply allowed by enabling the organisation to operate rather than outperform rivals in the industry. Finally, if the resulting resource stock is irrelevant to the organisation, the implementation of dynamic capabilities can lead to failure.

For the purposes of this research, the theory of dynamic potential is used as an anchor theory. The reason for using this theory is that it shares a common premise with the company's resource-based theory. However, it combines both internal and external FBO leadership skills that are essential to superior success and sustainability when considering turbulent religious environments. 


\subsection{People Management Skill and Sustainable Competitive Advantage: Review of Empirical Studies}

Hammadamin and Atan (2019) investigated the effect of strategic human resources management strategies on the achievement of sustainable competitive. The authors examined the mediating role of the creation of human resources and the engagement of workers in an academic setting. Six hundred copies of questionnaires randomly distributed to employees of selected universities in Erbil Region, Iraq, were the sample size used for the analysis. Using Structural Equation Modelling (SEM) methods and Smart Partial Least Square PLS, the data was analysed. The study results showed a linear and optimistic effect of the strategic practice of human resources management on the sustainability of competitive advantages. Strategic practice in the management of human resources has also been found to have a beneficial effect on the growth of human capital and the dedication of workers to organisations. The relationship between the production of human capital and the engagement of employees has been found to have a partial impact on mediation in the strategic activities of human resources management and sustainable competitive advantage.

Ibrahim and Oli (2019) explored strategic management's impact on the competitive advantage, growth and enhancement of organisational entrepreneurial skills. The population consisted of forty (40) small and medium-sized business managers working in Abuja, Nigeria. Normal termination of random sampling was employed. Using a five-point Likert scale, the study made use of the primary data source via questionnaire distribution. Pearson Product Moment Correlation was used, with the aid of the Statistical Package for Social Sciences (SPSS 20.1), to test hypotheses. The findings showed that organisations that have seen a positive effect of strategic leadership on the growth and development of entrepreneurial skills are those that have provided training based on the acquisition of entrepreneurial skills. Therefore, the study suggested investing in the preparation of its workers, as the human resource is an essential internal strength of each organisation and is therefore a source of competitive advantage for the organisations.

Asadu, Onah and Adumah (2020) explored the processes and imperatives of strategic human resources training and development to actualization of employees' and organisations' goals. The methodology of the work is qualitative and descriptive. Relevant data for the study were gathered via documentary source and structured oral interview administered to select management officers and employees. The generated data were analysed using descriptive analytic technique. The study, among other things, revealed that regular cum strategic training and development of workers in an organisation is indispensable for enhanced employees' commitment, performance and productivity. It also established that integration of employees' and organisational goals into training and development programmes is strategic for their mutual success

Mulolli, Boskovska and Islami (2020) examined the relationship between human resource management strategies (HRMs) and their effect on the competitive advantage of companies. It explores the strategic objectives of human resources and their effect on the development of the competitive advantage of the organisation through two HRM practices: (a) training and growth, and (b) compensation and remuneration of employees. From a self-administered questionnaire, the data used in this analysis was collected. The respondents were randomly selected. The results show that the strategic priorities of human resources have a positive effect on the achievement of the competitive advantage of organisations, and that job-specific preparation has the greatest impact on the achievement of high company efficiency. The findings of this study include and endorse the assertion that HRM investments improve employers' enthusiasm and thus increase the ability of an organisation to gain a competitive advantage.

\section{RESEARCH METHODOLOGY}

This study adopted review research design (qualitative approach) to explore the topic to unearth an in-depth understanding of specific knowledge gaps among FBOs owners and leaders in Nigeria. This is to know in regards to strategic people management skills demonstrated toward addressing competitive advantage and its implications on their long-term sustainability. To address this gap in the leadership literature and research problem, collection of data was used from multiple sources including historical, seminars and current peerreviewed papers (in some databases like Google Scholars, Sage, Ebsco, Elsevier, among others), tertiary sources such as electronic and print media reports, and other online reports etc. Data triangulation was conducted in order to establish the trustworthiness of the findings on the phenomenon. The study is aimed to add to the body of knowledge in the theoretical conceptualizations of strategic leadership management in Nigerian FBOs context.

However, the focus is to gather qualitative data in the selected states in Nigeria. Still, due to lack of time and restriction imposed by the Federal Government of Nigeria on general lockdown and restriction on inter-state movement, the reality made impossible. The researchers, therefore, decided to use existing literature to 
explore the study phenomenon. In corroboration with observations of authors, the earlier choice of using indepth interviews with faith-based organisations followers was declined by most respondents approached due to the same restrictions and the concern for their survival and general loss of interest in participating.

This is considered appropriate to give a summary and critical analysis of relevant research based on the objectives of this study. Conceptual analysis is used as the method of data analysis. Various concepts pertinent to this study are critically discussed and analysed. The phrases strategic people management skills and sustainable competitive advantage are searched in keywords, titles or abstracts to evaluate the issues of strategic leadership in the sustainable competitive advantage of FBOs in general.

\section{DISCUSSION OF FINDINGS}

In the Nigerian context, research found that the growth of Pentecostal churches in Kaduna State, Nigeria was influenced by a major gap in opinions between men and women on leadership styles. Another research also studied the church and the alleviation of poverty in Nigeria. It was discovered that, among others, policies and initiatives had failed due to corruption and bad design and execution. Similarly, some disclosures, such as return on assets, operating expenses and asset turnover, had a significant negative relationship with operating efficiency in the analysis of the effect of operational efficiency and financial sustainability of the manufacturing companies listed in Nigeria. The growth of staff, account receivable turnover and inventory turnover were found to have an insignificant operating efficiency relationship.

These findings revealed that in the Nigerian context, there is a need to rethink the link between strategic people management skills and sustainable competitive advantage in order to confirm, deny, or change scholars' established claims. In these fields, this study is an effort to bridge the gap in the literature that affects the work climate of Nigerian leadership in organisations.

\section{CONCLUSIONS}

In their incorporation for organisational use to achieve sustainability, the paper shows the notions of strategic people management skills and competitive advantage. It addressed how the dimensions of strategic people management skills can impact organisational stakeholders, most importantly leaders, managers and workers, as vital forces to build successful and productive organisational activities. The results of this study are based on the findings that the strategic capacity to handle people has a substantial effect on FBOs' sustainable competitive advantage. This means that it would improve their sustainable competitive advantage if $\mathrm{FBO}$ s pay attention to clearer and unambiguous strategic policies concerning human resources and motivational factors in their organisations.

\subsection{Acknowledgement}

The authors would like to acknowledge the leadership of Covenant University, Ota, Ogun State, Nigeria, through the Covenant University Centre for Research, Innovation and Discoveries (CUCRID), for supporting the entire research processes. The authors also appreciate the efforts of Prof. Evans Osabuohien, Chair of the Centre for Economic Policy and Development Research (CEPDeR), Covenant University, Ota, Ogun State, Nigeria, who gave his time for a palliative analysis and the final draft of this work to be completed.

\section{REFERENCE LIST}

Abasilim, U. D., Gberevbie, D. E. \& Osibanjo, O. A. (2019). Leadership styles and employees' commitment: Empirical evidence from Nigeria. Sage Open, 1(1), 1-15.

Abioro, M. A., Olabisi, J., Onigbinde, I. O., \& Adedeji, A. M. (2020). Skill Mapping, Talent Pool Management and Organisational Development: Evidence from Professional Bodies in Nigeria. Economics and Business, 34(1), 46-59.

Aboramadan, M. \& Borgonovi, E. (2016). Strategic management practices as a key determinant of superior non-governmental organisations performance. Problem of Management in the 21st Century, 11(2), 7192.

Ahmed, K. A. (2017). The influence of development on managerial capabilities and performance: Empirical evidence from Pakistan. Journal of Southeast Asian Research, 1(1), 1-12.

Akaegbu, J. B. \& Usoro, A. A. (2017). The place of organisational capabilities in strategy

formulation and implementation: An exploratory analysis. Global Journal of Social Sciences, 16(1), 39-48. 
Akande, O. O. (2016). Effects of training and development on improved performance of the ministerial staff of the Redeemed Christian Church of God (M.Sc Dissertation). Department of Business Administration, Redeemers University, Ede, Osun State.

Amir, A. H. \& Muathe, S. M. (2018). Strategic change management and performance of non-governmental organisations in Mandera County in Kenya. International Journal of Innovation Education and Research, 6(6), 87-96

Armstrong, M. (2017). Armstrong Handbook of Human Resources Management practice (12 ${ }^{\text {th }}$ edition). UK: Ashford Colour Press.

Asadu, I., Onah C. C., and Aduma, A., (2020). Strategic human resources training and development: a methodical exposition of the processes and bearings on accomplishment of employees' and organisations' goals. Arabian Journal of Business and Management Review (Nigerian Chapter), 6(1), 1-13.

Ayankola, I. A., \& Popoola, S. O. (2020). Effects of work motivation and self-esteem on career fulfilment among health information management personnel in Federal Teaching Hospitals in Southern Nigeria. Journal of Human Resource Management, 8(2), 85-95.

Baiyeri, H. B. (2013). The role of Faith-based organisations (FBOs) in Human Development: A study of Kogi State (MA Dissertation). University of Nigeria, Nsukka.

Barney, J. B. (1991). Firm resources and sustained competitive advantage. Journal of Management, 17(1), 99-120.

Brimah, B. A., Bamidele, A. G., Rabiu, R. O., \& John, I. S. (2020). The Conexus of Management by Objectives and Organisational Performance: Evidence from Tuyil Pharmaceutical Limited, Ilorin. Socio-Economic Challenges, 4(2), 90-98.

Cascio, W. F. \& Montealegre, R. (2016). "How technology is changing work and organisations". Annual Review of Organisational Psychology and Organisational Behaviour, 3(1), 347-375.

Cegliński, P. (2016). The concept of competitive advantages. Logic, sources and durability. Journal of Positive Management, 7(3), 57-70.

Clarke, G. (2015). Development, civil society and FBOs: Bridging the sacred and the secular. Basingstoke: Palgrave Macmillan.

Elumah, L. O., Shobayo, P. \& Adeleke, G. S. (2017). Human resource management practices and corporate financial performance: An empirical study of public and private companies in Nigeria. Pakistan Research Journal of Management Sciences, 1(1), 20-27.

Grant, R. M. (1991). The resource-based theory of competitive advantage: Implications for strategy formulation. California Management Review, http://doi.org/10.2307/41166664.

Glosnek, S. (2017). Comparing Christian FBOs and Secular NGOs in Guatemala: A qualitative assessment of individual motivations and organisational effectiveness. (M.A. Thesis) Department of Political Science, University of Guelph, Ontario-Canada.

Hamadamin, H. H., \& Atan, T. (2019). The impact of strategic human resource management practices on competitive advantage sustainability: The mediation of human capital development and employee commitment. Sustainability, 11(20), 5782.

Ibrahim, U. A., \& Oli, F. (2020). Effect of Strategic Management on the Development of Entrepreneurial Competency in Nigeria. European Journal of Business and Management, 12(3), 171-180.

Ireland, R. D. \& Hitt, M. (2015). Achieving and maintaining strategic competitiveness in the 21st century: The role of strategic leadership. The Academy of Management Review, 13(1), 43-57.

Mulolli, E., Boskovska, D., \& Islami, X. (2020). The Competitive Role of Human Resource Management Strategies on SMES in a Transitional Economy. International Journal of Multidisciplinary and Current research, 8.

Nwokoro, C. V. (2017). Assessing the distinctiveness of FBOs in the development sector in Nigeria. Journal of Humanities and Social Policy, 3(2), 1-16.

Nzisi, B. M. (2017). Leadership in small Christian communities and its effect on parish strategy: A case of St Francis Catholic Church in Kasarani, Nairobi, Kenya (Ph. D. Dissertation). United States International 
University-Africa.

Okoronta, G. O. (2015). The impact of leadership styles in the Pentecostal churches on growth of the gospel in Kaduna State (M. A. Dissertation). Ahmadu Bello University, Zaria, Nigeria.

Olofinkua, V. K. (2020). Academic Staff's Job Satisfaction and Motivation in Catholic Universities in Nigeria (Doctoral dissertation, Fordham University).

Oyedepo, D. O. (2016). Leadership fundamentals: Uncovering the missing links. Covenant University Executive Advance August, 2016.

Para-Mallan, G. (2019). An existential threat to Christianity in Nigeria: Systemic persecution and its implications. Lausanne Global Analysis, 8(4), 12-25

Sukier, H., Ramírez Molina, R. I., Parra, M. A., \& MARTINEZ CUETO, K. A. R. O. L. (2020). Strategic human resource management from a sustainable approach. Opcion, 1(1), 1012-1587.

Tomalin, E., Haustein, J. \& Kidy, E. (2018). Thinking about FBOs in development: When have we got to and what next? Development in Practice, 22(5-6), 689-703. 